

\section{Daftar Isi (Table of Content) Journal of Government
Civil Society}

\begin{tabular}{|c|c|}
\hline \multirow{3}{*}{$145-158$} & $\begin{array}{l}\text { Political Law's Reconstruction of Village Apparatus to Realize Independent } \\
\text { Village in Indonesia }\end{array}$ \\
\hline & Hartati $^{1}$, Pahrudin HM$^{2}$, Elita Rahmi ${ }^{1}$ \\
\hline & $\begin{array}{l}\text { ('Faculty of Law, Universitas Jambi, Indonesia) } \\
\text { ('Departement of Government Science, STISIP Nurdin Hamzah Jambi, Indonesia) }\end{array}$ \\
\hline \multirow{3}{*}{$159-179$} & $\begin{array}{l}\text { Policy of a Merit System to Make a Good and Clean Government in The } \\
\text { Middle of Bureaucratic Politicization }\end{array}$ \\
\hline & $\begin{array}{l}\text { Yahya Pandega Putra1, 2, Eko Priyo Purnomo, 2, Suswanta Suswanta1, } \\
\text { Aulia Nur Kasiwi1, }\end{array}$ \\
\hline & $\begin{array}{l}\text { ('Jusuf Kalla School of Government, Universitas Muhammadiyah Yogyakarta, Indonesia) } \\
\text { ('Department of Government Affairs and Administration, Universitas Muhammadiyah } \\
\text { Yogyakarta, Indonesia) }\end{array}$ \\
\hline \multirow{3}{*}{$181-199$} & $\begin{array}{l}\text { Smart Human Security: Economic Safety for Micro, Small and Medium } \\
\text { Enterprises (MSMEs) to Face The Impact of The Covid-19 Global Pandemic }\end{array}$ \\
\hline & Elyta $^{1}$, Warjio ${ }^{2}$, Ahmad Azrin Bin Adnan ${ }^{3}$ \\
\hline & $\begin{array}{l}\text { ('Faculty of Social and Political Sciences, Universitas Tanjungpura, Indonesia) } \\
\text { ('Faculty of Social and Political Sciences, Universitas Sumatera Utara, Indonesia) } \\
\text { ('Faculty of Business and Management, Universiti Sultan Zainal Abidin (UnisZa), } \\
\text { Trengganu, Malaysia) }\end{array}$ \\
\hline \multirow{3}{*}{$201-218$} & $\begin{array}{l}\text { Using The "Return on Investment" Strategy to Sustain Logistic Supply } \\
\text { Provider Toward Indonesia's Logistic Policy }\end{array}$ \\
\hline & Riska Rahayu $\mathbf{u}^{1,2}$, Eko Priyo Purnomo ${ }^{1,2}$, Ajree Ducol Malawani,1,3 \\
\hline & $\begin{array}{l}\text { ('1usuf Kalla School of Government, Universitas Muhammadiyah Yogyakarta, Indonesia) } \\
\text { ('Magister of Government and Public Affairs, Universitas Muhammadiyah Yogyakarta, } \\
\text { Indonesia) } \\
\text { ('Doctoral Program of Political Islam, Universitas Muhammadiyah Yogyakarta, Indonesia) }\end{array}$ \\
\hline \multirow{3}{*}{$219-228$} & $\begin{array}{l}\text { Indonesia Universal Health Coverage Implementation on University } \\
\text { Students }\end{array}$ \\
\hline & Adityo Pratikno Ramadhan'1, Budiyono Budiyonoㄹ, Djonet Santoso' ${ }^{1}$ \\
\hline & ('Sustainable Development Goals Center, Universitas Bengkulu, Indonesia) \\
\hline
\end{tabular}


The Local Government of Kulon Progo Regency Innovation in Subduing Capitalism through Community Empowerment

229 - 247 Muhammad Eko Atmojo ${ }^{1}$, Helen Dian Fridayani ${ }^{2}$

('Departement of Government Science, Universitas Muhammadiyah Yogyakarta, Indonesia)

('Departement of Political Science, National Cheng Kung University, Taiwan)

Land Administration Policy In Bantul and Sleman Districts

$249-272$

Subekti Widiyasno1, Dyah Mutiarin 1, Herdin Arie Saputra1, Ikhwan

Rahmatika Latif ${ }^{1}$

('Department of Government Affairs and Administration, Universitas Muhammadiyah Yogyakarta, Indonesia)

Increasing Local Own-Source Revenue through The Development of The Regional Tourism Sector

$273-291$

Harries Madiistriyatno', Ida Musdafia Ibrahim², Dudung Hadiwijaya ${ }^{3}$

('Program Studi Magister Manajemen Sekolah Tinggi Manajemen IMMI, Indonesia) (2Program Studi Manajemen Sekolah Tinggi Ilmu Ekonomi Y.A.I, Indonesia)

(3Program Studi Manajemen, Universitas Muhammadiyah Tangerang, Indonesia) 


\title{
Using The "Return on Investment" Strategy to Sustain Logistic Supply Provider Toward Indonesia's Logistic Policy
}

\author{
Riska Rahayu ${ }^{1,2 *}$, Eko Priyo Purnomo ${ }^{1,2}$, Ajree Ducol Malawani ${ }^{1,3}$ \\ ${ }^{1}$ Jusuf Kalla School of Government, Universitas Muhammadiyah Yogyakarta, Indonesia \\ ${ }^{2}$ Magister of Government and Public Affairs, Universitas Muhammadiyah Yogyakarta, Indonesia \\ ${ }^{3}$ Doctoral Program of Political Islam, Universitas Muhammadiyah Yogyakarta, Indonesia \\ *Email Correspondence: rskarahayu@gmail.com
}

\begin{abstract}
The purpose of this paper is to analyze the strategies carried out by Supply Logistics in the supply chain using supply chain management analysis also to facilitate the logistics chain in Indonesia. SCM previous research did not have a studio that discussed supply chain by manager logistics strategies and what methods they used to maintain logistics inventory. The research methodologists carried out using qualitative adopted an exploratory data analysis (EDA) approach to qualitative research that defines and explains the issues obtained. Open coding was applied to find issues the most dominant and was used to classify the number of issues related to the data and visualized into word cloud obtained using NVIVO 12 Plus. Data were collected from Indonesia logistic supply chain sites. The findings of this article is ROI (Return on Investments) is a logistics strategy will support for reducing the investment costs by logistics provider company. Analysis of supply chain management can develop better emphasizes logistic chains in Indonesia.
\end{abstract}

Keywords: Strategic, logistic chain, supply chain management

\begin{abstract}
ABSTRAK
Dalam artikel ini memiliki tujuan untuk menganalisis strategi dalam tantangan penyaluran logistic yang merata. Dengan menggunakan analisis sistem Supply Chain Management (SCM) yang akan memetakan strategi apa yang dilakukan Indonesia dalam tantang penyaluran logistik. Studi SCM terdahulu telah banyak adanya, namun tidak berfokus pada penyaluran logistik dalam strateginya untuk menjaga keseimbangan rantai pasokan logistik. Penelitian ini menggunakan metode kualitatif yang mengadopisi pendekatan Exploratory Data Ananlysis (EDA) untuk menjelaskan dan mendefinisikan temuan masalah. Open Coding dikukan untuk menemukan topik dan mengklasifikasikan yang dominan dan memvisualisasikannya menjadi word cloud dengan NVIVO 12 Plus. Data diperoleh dari website logistic supply chain Indonesia. Temuan dari artikel ini adalah Return on Investments (ROI) adalah strategi yang digunakan dalam strategi logistik yang akan membantu mengurangi dengan melakukan investasi dari beberapa perusahaan penyaluran logistik. Analisis SCM dalam penyaluran logistik dapat mengembangan tekanan tantangan logistik di Indonesia.
\end{abstract}

Kata Kunci: Strategi, tantangan logistik, supply chain management

Citation : Rahayu, Riska, Eko Priyo Purnomo, and Ajree Ducol Malawani. 2020. "Using The "Return on Investment" Strategy to Sustain Logistic Supply Provider Toward Indonesia's Logistic Policy." Journal of Government and Civil Society 4(2):201-218. 


\section{INTRODUCTION}

Consumer demand for high-quality and safer logistic have led to proposals on innovative approaches and models to be adopted in supply chain (Bhat \& Joudu, 2019). In the global context, there are several sustainability challenges along the logistic supply chain (Fassam \& Dani, 2017). Some of the innovative solutions proposed (depending on the socioeconomic and environmental factors) are practically applicable only in certain regions of the world. Sustainability challenges in the "farm-to-fork" concept are well documented in the literature and available database (Szerb, Horváth, Szerb, \& Csonka, 2020). However, several sustainability challenges in supply chain management still remain unresolved (Bhat \& Jõudu, 2019). These problems range from production and processing stages, all the way to the consumers. Man- aging the pressure exerted by consumers (regarding quality and safety) has led to potential negative and positive impacts. Even though logistics production has increased to meet the demands of ever-growing populations, rising prices and economic impacts/hardships on individual regions (lowincome and high-income countries) remains as a securing problem. On a global basis, with free-trade policies gaining a higher hand, the "trade revolution" has gained the upper hand over the "green revolution" (Bhat \& Jõudu, 2019). Coupled with this are the changing weather patterns which have had a significant effect on the food supply chain. Nevertheless, the food-energy-water nexus is vital to effectively manage the agry-supply chain and environmental stewardship. Besides, in the logistic supply chain context, life cycle assessment is recognized as a reliable method to evaluate the environment impacts of various processes (such as farming, harvesting of raw materials, processing, packaging, etc.) (Ansari \& Kant, 2017; de Oliveira, Espindola, da Silva, da Silva, \& Rocha, 2018; Liu, Bai, Liu, \& Wei, 2017). Not to forget, reduction in the carbon footprint should be one of the crucial factors to ensure and create a sustainable logistic supply chain system (Xu \& Gursoy, 2015).

Logistics plays a vital role in the supply chain (Lamba \& Singh, 2017; Szerb et al., 2020). The opening up of the global market and trade, it also opens up opportunities for businesses to extend the region would generate competition for logistics supply between areas and between countries (Gregory, 2019). With the area of $1.905 \mathrm{~km}^{2}$ million with 34 provisions, Indonesia faced with the Logistics Supply issue, which tends to be lower in distribution compared to other countries. As can be seen from the following data bellow: 


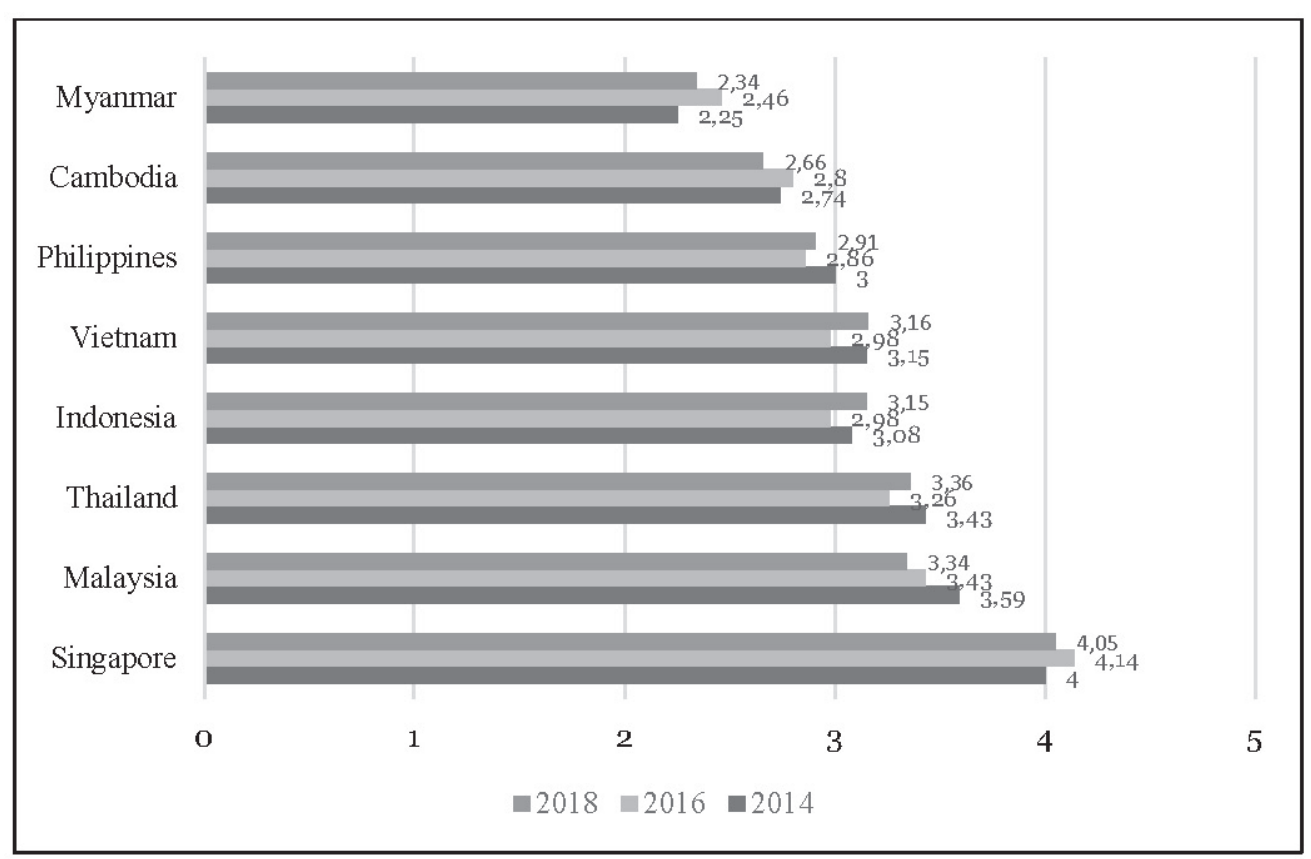

Figure 1. Logistic Performance Index Sources: World Bank, 2016-2018

The above data indicates that Indonesia can compete with many other ASEAN countries in the Logistics Supply market, achieving the highest score of 3.15 on 2018s. Indonesia is also unable to incorporate Logistics Supply, as Singapore has the highestranking concerning other nations. Of course, key logistics decisions can be of much help in meeting environmental sustainability challenges faced in the logistics supply chain. Certain regions of the world, though claiming to be economically stable, have never established a positive relationship between diversity and logistics self-sufficiency. Lowand middle-income groups of countries are having their own problems in the food supply chain that need to be resolved, such as feeding and meeting the demands of their own population as well as competing in the global food markets. Elementary sustainability issues valuable from a socio-economic and environmental perspective have been discussed under the millennium and sustainable development goals of the United Nations (UN, 2014). Further, the logistic supply chain is recognized as a series of closely working interdependent firms/companies that manage the smooth movement of agri-food products (for value addition) to provide consumers with high-quality products at affordable prices (Bhat \& Jõudu, 2019).

However in today's world, the corporate climate has evolved, and any enterprise or corporation works in a competitive and fast-moving market owing to the effects of globalization and other unavoidable variables such as technical innovation, 
competitiveness, rising consumer demands, and geopolitical influences (Diversity et al., 2011). An organization-based management strategy that has persisted for many years is no longer sufficient and underpinned by a modern market climate to provide the products and services provided to consumers because companies become part of the supply chain and the supply chain wins or loses competitiveness (Kshetri, 2018). Supply chain management plays a crucial role in improving the successful and productive management of finite capital to allow businesses and organizations to achieve the objectives set (Lamba \& Singh, 2017; Maji \& Arora, 2017). Supply Chain Management as solutions to the effective management of manufacturing infrastructure and the delivery of products to consumers by the collaboration of multiple Supply Chain players in the network (Ejeta, 2018). Supply chain management is a function of combining operational structures around the supply chain and managing products, knowledge, and financial flows in order to satisfy final consumer demands to enhance the profitability of the supply chain as a whole (Kazancoglu, Kazancoglu, \& Sagnak, 2018; Loisel, 2017).

The principle of effective supply chain management includes the control of resources, knowledge, and capital movements between the stakeholders participating in the supply chain for a shared objective of socio-economic and environmental sustainability growth (Fernandes, Sampaio, Sameiro, \& Truong, 2017; Mangla et al., 2018). Of late, (Esfahbodi, Zhang, \& Watson, 2016) a conceptual concept based on expense processes, including sourcing and delivery, architecture, and expenditure recovery solutions, has been suggested sustainably. The position of technical advances and their effect on the logistics sector (demand, demand development, and supply chain) has been well reported. (de Oliveira et al., 2018; Kaur, Sidhu, Awasthi, Chauhan, \& Goyal, 2018). The idea of convergence of the supply chain includes shared awareness, technical alliances, and practical/operational competitive operations between organizations in the line. Supply chain convergence has been envisaged to bring the whole network connected in a continuous system, while helping to minimize persistent supply chain problems, such as weak demand-based control, planning, and preserving customer and manufacturer knowledge and relationships (Kinyua, 2013). As a result, the supply chain is autonomous and requires control and movement through various industries, such as aquaculture, forestry, poultry, dietary additives, organic production, industrial cultivation, cold chain control, dairy farming, limited manufacturing, and many more (Bhat \& Jõudu, 2019).

Supply chain management is a direct reflection of demand chain management, where manufacturing, storage, refining, and delivery, as well as promotion, are customized to the needs of customers (Fahimnia, Pournader, Siemsen, Bendoly, \& Wang, 2019). There is a large degree of ambiguity about the quality and health of logistics goods relative to market-driven purchase costs such as knowledge, bargaining, or tracking (Bhat \& Jõudu, 2019). Organizations choose to cooperate with other entities in the supply chain and develop partner relationships to improve their global market competitiveness (Yalcin, 
Shi, \& Rahman, 2020). Internationalization in supply chain management has contributed to dynamic business strategies at the regional level (Tseng, Islam, Karia, Fauzi, \& Afrin, 2019). At the international stage, in terms of manufactured logistics, customers are far more involved in understanding the country (geographical origin), enforcement of environmental regulations, ethical concerns, and whether or not sustainable food processing has been implemented (Akhtar, Marr, \& Garnevska, 2012; Balcik, Beamon, Krejci, Muramatsu, \& Ramirez, 2010; Szerb et al., 2020).

Despite increase in demand for humanitarian assistance in different parts of the world, humanitarian organizations are experiencing a number of supply chain management challenges (Gregory, 2019; Y.K Sharma, 2018). For example, according to Ejeta, (2018) supply chain management challenges that humanitarian organizations face include frequent turnover of employees, level of knowledge of humanitarian organizations and capacity of the stakeholders, dilemma of donors in terms of providing funds for the humanitarian operations. Moreover, Kinyua, 2013 identified supply chain challenges of food supply organizations which are related to supply chain coordination, capacity of local transport, warehousing capacity, facility at the port and government policies. It is known that challenges associated with supply chain can lead to delays in delivery of humanitarian supplies to the affected people and increasing cost which ultimately leads to huge loss of life (Nyamu, 2012). Logistic supply chain management challenges contributed to inefficiency and ineffectiveness of the entire supply chain process in delivery of the humanitarian supplies by increasing operational costs and lead time which ultimately reduce performance of the organization (Ejeta, 2018).

According to Balcik (2010) there are a number of players and actors involved in humanitarian relief environments to supporting chain of supply. These actors are international relief organizations, host government, the military, local and regional relief organizations, and private sector companies. Roles, areas of expertise and focus areas of these actors differ in the entire process of humanitarian supply chain. Apparently, a single actor may not have the required resources in terms of human capital, funding sources and other resources to respond effectively to any disasters, hence the need for coordination is relevant. Balcik (2010) further described coordination as the fundamental and core element of supply chain management. The objective of food supply chain is to effectively respond to both man-made and natural disasters. These disasters are very common across the world and can cause loss of lives, shortage of food and water and other serious damages. Hence, the coordination among humanitarian organizations and other stakeholders is a necessity and fundamental during such situations due to the fact that a single organization (Purnomo, 2012). It is not in a position to meet and fulfill the entire demands of people affected by disaster such as providing food, water, medicines and other basic supplies (Akhtar et al., 2012; Gregory, 2019). These organizations usually 
share the resources they mobilize for the purpose of responding to humanitarian assistance and work together to achieve their objectives. This system of interdependency is called coordination (Akhtar et al., 2012; Gregory, 2019). Balcik, 2010 also defined the term coordination as "the relationships and interactions among different actors operating within the relief environment".

There is a substantial number of variables in the literature to discussing logistic supply management, generally divided into three main categories based on (Yazdani, Zarate, Coulibaly, \& Zavadskas, 2017):

1. RL/CLSC strategic decision variables: Designing decisions, like locations and capacities of facilities (configurations and structures), are made at this level. These are long-term decisions.

2. RL/CLSC planning decision variables: Include decisions regarding which markets will be supplied from what locations (allocation level), and flow of supply chain network. These are mid-term decisions.

3. RL/CLSC operational decision variables: Include allocating inventory or production to individual orders, setting a date by which the order is to be filled, and other shortterm decisions.

As various types of decision variables are defined and researched by different authors, we review these decision variables in and illustrate that portion of each variables in this papers that consider to strategic in logistic supply (Govindan, Soleimani, \& Kannan, 2015). Indonesia supported by a range of laws that support the Logistics Supply Chain, including Act No. 23/2007, Act No. 1/2009, and Act No. 22/2009. In the Government Act No. 85/2015 concerning amendments to PP No. 32/2009 concerning bonded stockpiles explained the rule of thumb in the Logistics Supply Chain, which is to bring the costs of industrial activity closer to economic activities to reduce logistics costs in improving services for business actors. Moreover, reinforcing in this study is the existence of Presidential Decree No. 026 of 2012 concerning the direction of the development of Indonesia's logistics system by relying upon one of the main factors of Indonesian logistics as logistics service providers. Also Government Act No. 69/2015 concerning the import and delivery of specific transportation equipment and the delivery of taxable services related to specific transportation equipment that is not subject to value-added tax regulated in the efforts to encourage the domestic shipping and shipyard industry with the PPN tax relief/exemption. To improving logistical performance in Indonesia, there is an increase in Logistics Performance Index (LPI), which requires systematic and integrated planning that involves relevant parties, namely the government that makes the rules, institutional integration with functions that adjusted so that can realize a better Indonesian Organization Logistics. 


\section{RESEARCH METHOD}

Considering logistic supply chain supporting food supply in Indonesia also improving logistical performance in Indonesia, there is an increase in Logistics Performance Index (LPI). Which requires systematic and integrated planning that involves relevant parties, namely the government that makes the rules, institutional integration with functions that adjusted so that can realize a better Indonesian Organization Logistics The research question is following how logistic supply chain consider to their Strategic according supporting supply system. This study used a qualitative research approach. This study adopted an exploratory data analysis (EDA) approach to qualitative research that defines and explains the characteristics of the distribution. The EDA consists of a description with the features of the criteria or metrics to be included (Ayyagari, 2012). For the proper processing of the data, a word processor was carried out with purposive sampling data, which random sampling technique was then used to determine specific characteristics that fit the purpose of the study (Bloor \& Wood, 2016).

Document-text was collected via Logistic Supply Chain websites. Supply Chain Indonesia (SCI) is an independent institution engaged in education, training, consulting, research and development activities in logistics and supply chains in Indonesia. SCI is a place for information, interaction and communication between scientists, academics, bureaucracy, researchers and observers in the field of logistics and supply chains in Indonesia. SCI has supported improving and improving logistics for private companies and State-owned enterprises (SOEs). SCI also contributes to the improvement and development of logistics through several ministries and related institutions, such as the Coordinating Ministry for Economic Affairs, the Ministry of Transportation, the Ministry of Trade, and others, including in the implementation of the National Logistics System Development Blueprint (SCI, 2020).

Open coding was applied to find issues the most dominant and was used to classify the number of issues related to the data obtained. After that, another task was performed as the final phase in the topic modeling process. Here, the number of topics listed was plotted automatically to found cloud. NVivo application is one of the qualitative research data to the analysis application that has been used by many qualitative Researchers around the world (Sotiriadou, Brouwers, \& Le, 2014). This application helps researchers visualize and categorize data interviews, and documentation. The limitation of this study is to analyze the logistical sustainability strategy of logistic service providers only from the Return of Investment (ROI) system. From this limitation, further research is needed to compare certain strategies with other strategies to improve logistics resilience as part of the logistics policy in Indonesia. 


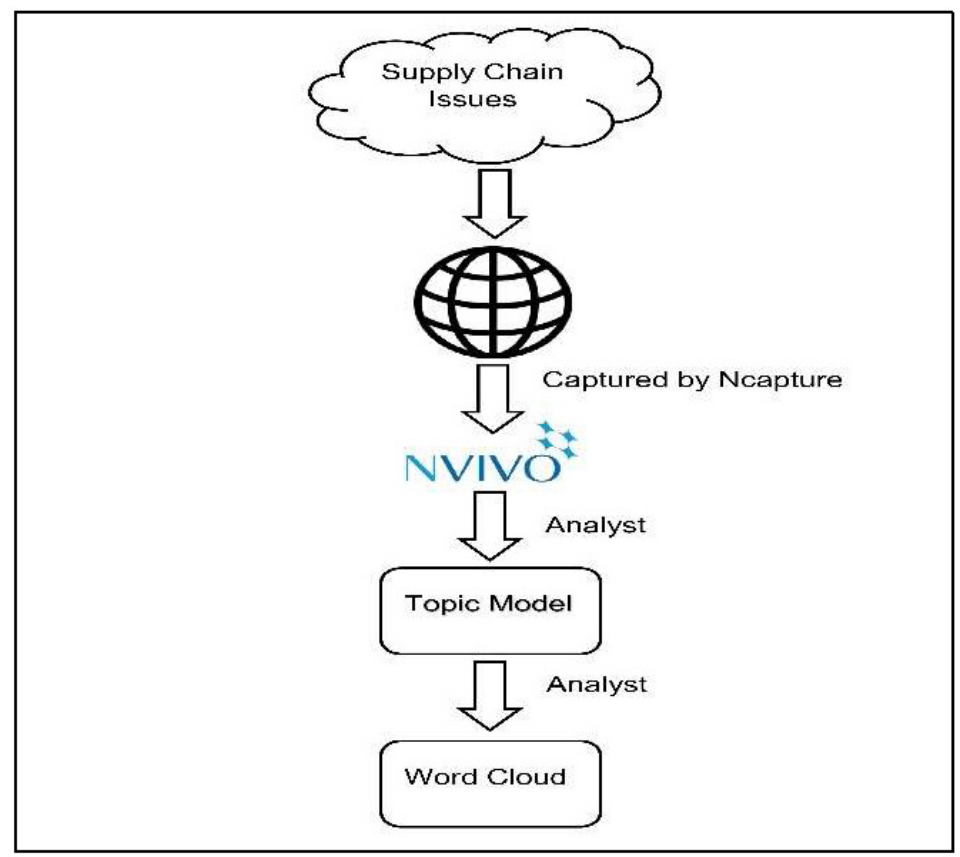

Figure 2. The Logic of Data analysis

Source: Author, 2020

\section{FINDINGS AND DISCUSSION}

Return on Investment (ROI) to Maintaining Logistic Supply

The logistics strategy executed by the company is manifold. Between companies, logistical strategies can be implemented. The logistics strategy decision taken will have implications for the company's financial performance. Organizational leaders can use logistical strategies to determine financial performance. Producing companies use Return on Investment (ROI) as a measure of financial performance.(Harvey, Despain, Lieberman, Canning, \& Bochman, 2010). ROI measures the company's financial performance from the perspective of investors, both equity investors, and creditor investors. ROI is a ratio that measures a company's profitability from the returns generated from the use of assets to generate sales (capital employed). Stated ROI calculated by dividing net income by assets. From this formula, to increase ROI, there are at least two factors that must improve the company, namely profit, and assets. Profit is the difference between sales and total costs. While assets were calculated, $\mathrm{ROI}$ is the asset used to generate sales. In many financial literature books, assets used to consist of cash, receivables, filled, and fixed assets (Harvey et al., 2010). 
Company organization leaders are trying to improve ROI, even though there is no exact standard for how much ROI should be achieved. ROI standards for each company differ depending on the industrial sector, company size, and investor expectations. In general, investors set ROI standards following the expected level of return, taking into account business risks according to the industry sector. In this case, the law "high risk and high return" applies. The higher the business risk, investors expect a high return or return. In financial literature, this return is proxied by several approaches or proxies. One of them is the CAPM (Capital Asset Pricing Model). This model proxy returns determined from parameters of the level of return on a risk-free investment, beta market returns, and the level of premium return which is the difference between market return and return on investment of risk-free assets (Harvey et al., 2010). Investors will place their funds in companies that generate high ROI. This is the duty of company managers always to maintain and improve ROI so that the companies managed to become the choice of investors.

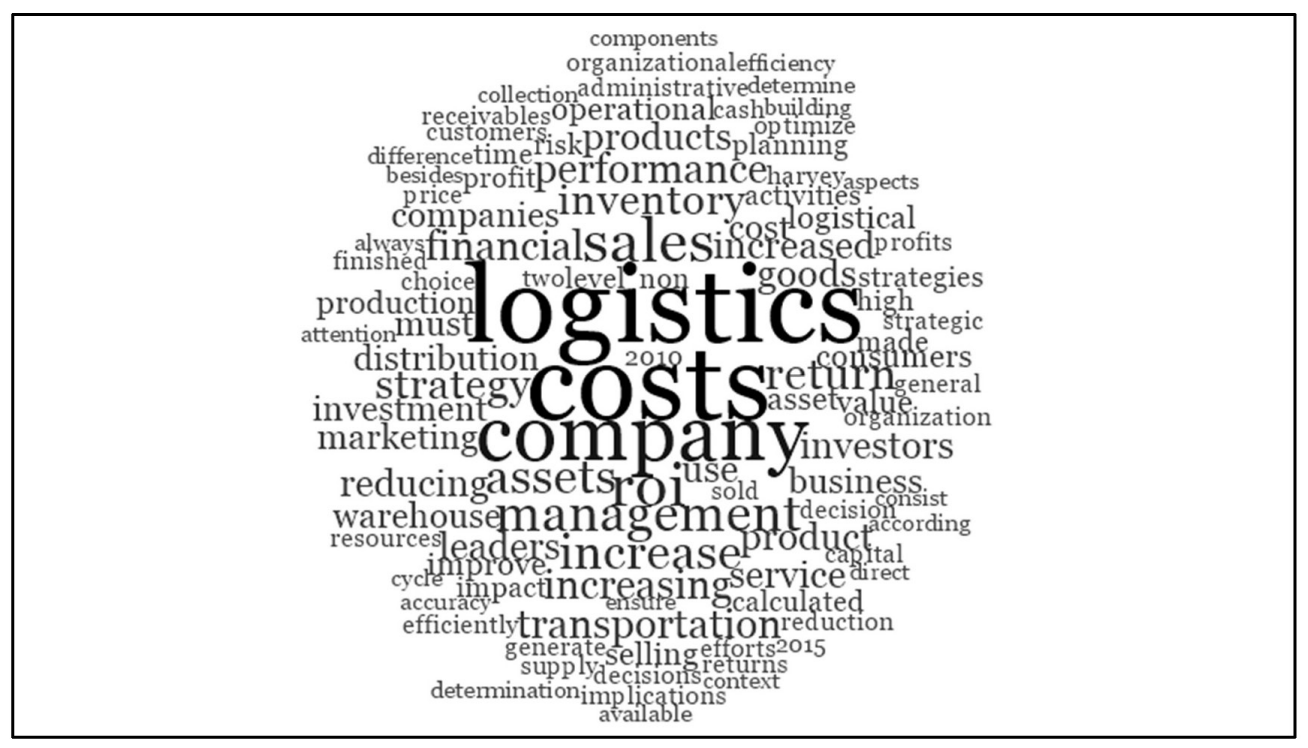

Figure 3. Cloud of Logistic Supply 2020 by NVIVO 12 Plus

Source: Author, 2020

Indeed the logistics strategy is intended to achieve logistical efficiency and effectiveness. Efficiency is defined as achieving the lowest logistics costs. While effective refers to the accuracy and reliability of the management of logistics activities, such as transportation, warehousing, and distribution, to ensure materials or goods are available when needed. These logistics activities include inbound logistics or often referred to as production logistics and outbound logistics or marketing logistics. This inbound logistics is to ensure that the 
materials and components (parts) are available according to production needs-logistics management for the distribution of finished products from factory warehouses or producers to final consumers. Management of logistics activities requires investment in infrastructures such as warehouses, vehicles, material handling equipment, ICT, and operational costs. The type and amount of logistics infrastructure that a company must prepare are influenced by the logistics strategy chosen.

Strategic planning has long-term implications. At least the strategic decisions taken by the company in the logistics strategy will have implications for the company's overall performance for the next five years. Decisions in planning this logistics strategy include distribution channels (channel of distribution), supply points, production locations, warehouse configuration, warehouse-type and number, warehouse location and size, transportation types and modes, logistics management self-managed (inhouse logistics) or using logistics service providers (third party logistics), distribution strategies, and inventory level policies. The choice of logistics strategy will determine the tactical planning and logistics operations, which will result in the investment and operational costs of the logistics company. These investments and operational costs are two essential components of ROI. Therefore, the choice of logistics planning decisions has an impact on the company's financial performance.

The first component of ROI is the profit calculated from sales minus total costs. In manufacturing companies, costs generally consist of the cost of goods sold, sales and marketing costs, administrative and general costs, and non-business costs. The cost of goods sold is calculated from the initial inventory of finished products plus the cost of production minus the final inventory of finished products. While sales and marketing costs are all costs incurred by the company to process sales orders, shipping, and distribution of products to consumers. Included in these sales and marketing costs are costs to get new customers, customer retention and promotions.

Administrative and general costs are usually the costs of running a company organization, for example, non-production employee salary costs, office building rental fees, office building depreciation costs, and others. While non-business costs are costs other than the company's operational costs, for example, the cost of loan interest. In the context of increasing ROI, management's attention is primarily to increase profits and optimize the use of assets efficiently. Increasing profits is made by increasing sales or reducing costs. Sales can be increased by increasing the selling price or increasing the sales volume of the goods. In marketing science, the selling price can be increased by increasing the "value" of products and services so that consumers are willing to pay more. This product and service value includes, among other efforts, to improve product quality, features, product usability, emotional aspects, service, and consumer experience in using products. The company's organizational leaders must always increase the value 
of this product through innovation and service improvement so that consumers enjoy a memorable experience. An increase in the selling price of a product without offset by an increase in product value will not be able to increase sales, rather than consumers turning to competitor products.

Besides increasing selling and selling prices, profit can also be increased by reducing costs. The attention of corporate organization leaders to increase profits by reducing the cost of goods sold, sales costs, marketing costs, administrative costs, and non-business costs. In the context of logistical strategies, sales increase is carried out in various ways, including (Paravisini, Rappoport, Schnabl, \& Wolfenzon, 2015):

Cost reduction is made through efforts to simplify business processes, reduce activities and resources that do not provide added value to customers, and the use of shared resources (sharing resources). From a logistics perspective, management's concern is to reduce logistics costs. The reduction of logistics costs is made (Govindan et al., 2015):

1. Management of transportation efficiently, through the determination of transportation designs, determination of routes, schedules, modes, types and capacities of transportation fleets, safety driving, and shipment consolidation. Efficient transportation management will have a direct impact on reducing transportation operating costs.

2. Management of warehousing efficiently through the use of warehouse management systems for storage, collection, and delivery of goods. Besides, inventory location and stock control policies need to be established that can optimize inventory management.

3. Reducing inventory levels through the application of EOQ (economic order quantity), $A B C$ inventory system, and JIT (just-in-time) approach. Inventory reduction will have a direct impact on reducing working capital that must be provided for stock.

No less important, in addition to increasing sales and reducing costs, company leaders must optimize the use of assets, both current assets such as cash, receivables, and fixed assets such as warehouse, MHE, and transport. This asset optimization is intended to increase asset turnover. Efforts that must be made by company leaders to increase asset turnover are (Gunders, 2012): (a) Increased cash cycle, reduced collection periods through managing trade receivables; (b) Increased cycle time order; (c) Increased inventory accuracy; (d) Optimizing warehouse space and transportation; (e) Logistics outsourcing to third-party logistics companies.

The company's management decision on a variety of logistics strategy choices will have an impact on infrastructure investment and logistics operational costs. These last two things ultimately affect the company's financial performance. Organizational leaders need to consider every logistical strategy decision to be executed carefully. 
World Bank indexed Logistics Performance Index (LPI) Survey in 2018 states that Indonesia is ranked 46th out of 155 ASEAN countries that participated in the survey. LPI uses six assessment indicators are: customs; infrastructure; ease of managing international shipping; logistics competencies; logistics costs in the country; and delivery time considerations. The score and sequence of Indonesia compared to several ASEAN countries in each assessment indicator can be seen in the following table.

Table 1. ASEAN Logistic Performance Index 2018

\begin{tabular}{|c|c|c|c|c|c|c|c|c|}
\hline \multirow{2}{*}{ Country } & \multicolumn{2}{|c|}{ LPI } & \multirow[t]{2}{*}{ Customs } & \multirow[t]{2}{*}{ Infrastructure } & \multirow{2}{*}{$\begin{array}{l}\text { Intern. } \\
\text { Shipments }\end{array}$} & \multirow{2}{*}{$\begin{array}{c}\text { Logistics } \\
\text { Competence }\end{array}$} & \multirow{2}{*}{$\begin{array}{c}\text { Tracking } \\
\& \\
\text { Tracing }\end{array}$} & \multirow[t]{2}{*}{ Timeliness } \\
\hline & Rank & Score & & & & & & \\
\hline \multicolumn{9}{|l|}{ ASEAN } \\
\hline Singapore & 7 & 4.00 & 3.89 & 4.06 & 3.58 & 4.10 & 4.08 & 4.32 \\
\hline Thailand & 32 & 3.41 & 3.14 & 3.14 & 3.46 & 3.41 & 3.47 & 3.81 \\
\hline Vietnam & 39 & 3.27 & 2.95 & 3.10 & 3.16 & 3.40 & 3.45 & 3.67 \\
\hline Malaysia & 41 & 3.22 & 2.90 & 3.15 & 3.35 & 3.30 & 3.15 & 3.46 \\
\hline Indonesia & 46 & 3.15 & 2.67 & 2.89 & 3.32 & 3.10 & 3.30 & 3.67 \\
\hline Philippines & 60 & 2.90 & 2.53 & 2.73 & 3.29 & 2.78 & 3.06 & 2.98 \\
\hline \multicolumn{9}{|l|}{ ASIA } \\
\hline Japan & 5 & 4.03 & 3.99 & 4.25 & 3.59 & 4.09 & 4.05 & 4.25 \\
\hline Korea, Rep & 22 & 3.68 & 3.29 & 3.46 & 3.75 & 3.72 & 3.70 & 4.13 \\
\hline China & 26 & 3.61 & 3.29 & 3.75 & 3.54 & 3.59 & 3.65 & 3.84 \\
\hline India & 44 & 3.18 & 2.96 & 2.91 & 3.21 & 3.13 & 3.32 & 3.50 \\
\hline
\end{tabular}

Source: World Bank, 2018

The low performance of the logistics sector in Indonesia is the high cost of logistics and the need to improve the quality of service, the low quality of infrastructure in terms of both quality and quantity, the high time of export and import services and the existence of operational obstacles in ports and the limited capacity and national logistics service network (Kaur et al., 2018; Urciuoli \& Hintsa, 2017). This is one of the leading causes of various national problems such as scarcity of food, price fluctuations, export barriers, disparities in supply and demand between regions to the slow distribution of aid in natural disasters. As a result of these problems, the impact is felt by people who have to pay high costs because of logistics and exports that are less able to compete at the level of free trade between countries. 


\section{Implication of Theory}

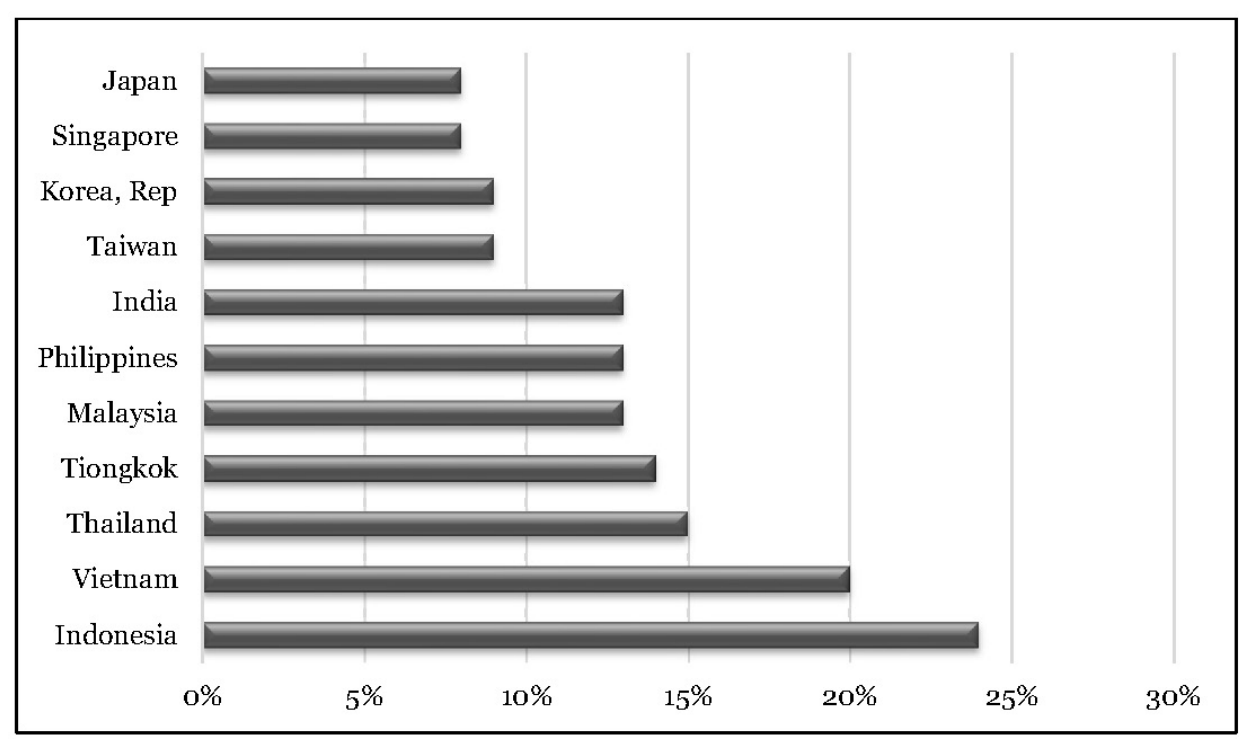

Figure 4. Indonesian Logistic Cost toward Gross Domestic Product (GDP) Source: BPPP. Kemendag, 2019

The high cost of logistics in Indonesia is not only caused by the high cost of land and sea transportation but also by many factors which are related to regulations, human resources, processes and infrastructure that have not been efficient and lack of professionalism of logical actors and service providers (developing companies). The data above explains that the logistics performance in Indonesia is a factor that greatly affects the competitiveness of national industries. This indicates that one of the causes of the low competitiveness of the industry during the last decade is due to the low performance of logistics which causes high national logistics costs.

Measuring become a concern for stakeholders is to improve supply chain management in Indonesia to developing better, are (Fernandes et al., 2017; Govindan et al., 2015; Mishra, Gunasekaran, Papadopoulos, \& Childe, 2018; Zhao, Liu, Zhang, \& Huang, 2017): First, emphasizing chain development and maintenance efforts, which means the establishment of relationships between chains more specifically such as volume, quality, distribution depending on the shortage in the business sector to form an integrated and interrelated pattern. Second, controlling the supply of supplies must be directed at cost efficiency; for example, the amount of supply is adjusted to the number of products that can be sold so that the stability of raw material inventory is generated and there is no stock build-up which increases storage costs (Esfahbodi et al., 2016). Thrid, in determining the location and transportation in the network chain, it is made by calculating and considering the 
impact on inventory costs. In this case, it will affect the level of consumer sensitivity. Therefore an evaluation of this is essential. Fourth, the establishment of an information system between the parties tasked with collecting, processing, storing and disseminating information to each stakeholder must be based on trust between them, at this moment supporting the performance and productivity of each member of the chain (Esfahbodi et al., 2016).

Return on investment (ROI) is one of the logistics suppliers approaches for the provision of logistics supplies in Indonesia. The business steps made by the organization in the Logistics Plans would have consequences for the financial success of the company for the next five years (Urciuoli \& Hintsa, 2017). Decisions of logistics strategy include distribution channels (channel of distribution), supply points, production locations, warehouse configuration. Through rising revenue and retail costs, ROI provides preference to growing the quality of production and revenues in order to raise the expense of logistics (Schmidt, 2019).

\section{CONCLUSION}

The complexity of logistics supply in supply chain management (SCM) systems is required; the logistics strategy is intended to achieve logistical efficiency and effectiveness. Decisions in planning this logistics strategy include distribution channels (channel of distribution), supply points, production locations, warehouse configuration, warehousetype and number, warehouse location and size, transportation types and modes, selfmanaged logistics management or in-house logistics using logistics service providers (third party logistics), distribution strategies, and inventory level policies. The choice of logistics strategy will determine the tactical planning and logistics operations, which will result in the investment and operational costs of the logistics company. These investments and operational costs are two essential components of Return on Investment (ROI).

Concerned the measure of supply chain management in Indonesia to developing better are emphasizing chain development and maintenance efforts; controlling the supply of supplies must be directed at cost efficiency; determining the location and transportation in the network chain; and establishing an information system between the parties tasked with collecting, processing, storing and disseminating information.

\section{REFERENCES}

Akhtar, P., Marr, N. E., \& Garnevska, E. V. (2012). Coordination in humanitarian relief chains: chain coordinators. Journal of Humanitarian Logistics and Supply Chain Management, 2(1), 85-103. https:// doi.org/10.1108/20426741211226019 
Ansari, Z. N., \& Kant, R. (2017). A state-of-art literature review reflecting 15 years of focus on sustainable supply chain management. Journal of Cleaner Production, 142, 2524-2543. https:// doi.org/10.1016/j.jclepro.2016.11.023

Ayyagari, R. (2012). An Exploratory Analysis of Data Breaches from 2005-2011: Trends and Insights. Journal of Information Privacy and Security, 8(2), 33-56. https:/ / doi.org/ 10.1080/15536548.2012.10845654

Balcik, B., Beamon, B. M., Krejci, C. C., Muramatsu, K. M., \& Ramirez, M. (2010). Coordination in humanitarian relief chains: Practices, challenges and opportunities. International Journal of Production Economics, 126(1), 22-34. https://doi.org/10.1016/ j.ijpe.2009.09.008

Bhat, R., \& Jõudu, I. (2019). Emerging issues and challenges in agri-food supply chain. Sustainable Food Supply Chains, 23-37. https:// doi.org/10.1016/b978-0-12-8134115.00002-8

Bloor, M., \& Wood, F. (2016). Purposive Sampling. Keywords in Qualitative Methods, I(01), 24-41. https:// doi.org/10.4135/9781849209403.n73

de Oliveira, U. R., Espindola, L. S., da Silva, I. R., da Silva, I. N., \& Rocha, H. M. (2018). A systematic literature review on green supply chain management: Research implications and future perspectives. Journal of Cleaner Production, 187, 537-561. https:/ /doi.org/10.1016/j.jclepro.2018.03.083

Diversity, G., Sesame, O. F., As, G. C., By, R., Marker, I., \& Improvement, C. (2011). Assessment of Humanitarian Supply Chain Management Challenges on Performance: The case of World Food Programme- Ethiopia. (July).

Ejeta, D. A. (2018). Assessment of Humanitarian Supply Chain Management Challenges on Performance: The cas of World Food Programme-Ethiopia. (July).

Esfahbodi, A., Zhang, Y., \& Watson, G. (2016). Sustainable supply chain management in emerging economies: Trade-offs between environmental and cost performance. International Journal of Production Economics, 181, 350-366. https://doi.org/10.1016/ j.ijpe.2016.02.013

Fahimnia, B., Pournader, M., Siemsen, E., Bendoly, E., \& Wang, C. (2019). Behavioral Operations and Supply Chain Management-A Review and Literature Mapping. Decision Sciences, 50(6), 1127-1183. https://doi.org/10.1111/deci.12369

Fassam, L., \& Dani, S. (2017). A conceptual understanding of criminality and integrity challenges in food supply chains. British Food Journal, 119(1), 67-83. https://doi.org/ 10.1108/BFJ-07-2016-0314

Fernandes, A. C., Sampaio, P., Sameiro, M., \& Truong, H. Q. (2017). Supply chain management and quality management integration: A conceptual model proposal. International Journal of Quality and Reliability Management, 34(1), 53-67. https:/ / doi.org/ 10.1108/IJQRM-03-2015-0041 
Govindan, K., Soleimani, H., \& Kannan, D. (2015). Reverse logistics and closed-loop supply chain: A comprehensive review to explore the future. European Journal of Operational Research, 240(3), 603-626. https:// doi.org/10.1016/j.ejor.2014.07.012

Gregory, P. (2019). CHALLENGES OF SUPPLY CHAIN MANAGEMENT IN FOOD STUFF DISTRIBUTIONS/: A CASE STUDY OF WORLD FOOD PROGRAMME IN TANZANIA By. (04).

Gunders, D. (2012). Wasted: How America is losing up to 40 percent of its food from farm to fork to landfill. NRDC Issue Paper, (August), 1-26. Retrieved from http:// w w w. n r d c. o r g / f o o d / f i l e s/ w a s t e d - f o o d IP.pdf?mkt_tok=3RkMMJWWfF9wsRonuqjPZKXonjHpfsX56+woXaS11MI/ 0ER3fOvrPUfGjI4ATMphI/qLAzICFpZo2FFUH+GbbIFU8g==

Harvey, W. M., Despain, G. L., Lieberman, M., Canning, B. P., \& Bochman, P. (2010). ANALYZING RETURN ON INVESTMENT OF ADVERTISING CAMPAIGNS BY MATCHING MULTIPLE DATA SOURCES (Vol. 2).

Kaur, J., Sidhu, R., Awasthi, A., Chauhan, S., \& Goyal, S. (2018). A DEMATEL based approach for investigating barriers in green supply chain management in Canadian manufacturing firms. International Journal of Production Research, 56(1-2), 312-332. https: / / doi.org/10.1080/00207543.2017.1395522

Kazancoglu, Y., Kazancoglu, I., \& Sagnak, M. (2018). A new holistic conceptual framework for green supply chain management performance assessment based on circular economy. Journal of Cleaner Production, 195, 1282-1299. https://doi.org/10.1016/ j.jclepro.2018.06.015

Kinyua, J. K. (2013). Supply Chain Integration And Supply Chain Performance Of International Humanitarian Organisations In Kenya. Retrieved from http:// erepository.uonbi.ac.ke:8080/xmlui/handle/123456789/59609\%5Cnhttp:/ / erepository.uonbi.ac.ke:8080/xmlui/bitstream/123456789/59609/1/ ABSTRACT.pdf\%5Cnhttp://www.imagine.mx/handle/123456789/59609

Kshetri, N. (2018). 1 Blockchain's roles in meeting key supply chain management objectives. International Journal of Information Management, 39(December 2017), 80-89. https:// doi.org/10.1016/j.ijinfomgt.2017.12.005

Lamba, K., \& Singh, S. P. (2017). Big data in operations and supply chain management: current trends and future perspectives. Production Planning and Control, 28(11-12), 877-890. https://doi.org/10.1080/09537287.2017.1336787

Liu, W., Bai, E., Liu, L., \& Wei, W. (2017). A framework of sustainable service supply chain management: A literature review and research agenda. Sustainability (Switzerland), 9(3). https://doi.org/10.3390/su9030421

Loisel, M. (2017). Labor-Force Management Challenges of Farms Involved in Short-Food. 
Maji, S., \& Arora, S. (2017). Information and Communication Technology for Competitive Strategies. In Proceedings of Third International Conference on ICTCS 2017 (Vol. 40). https:/ / doi.org/10.1007/978-981-13-0586-3

Mangla, S. K., Luthra, S., Mishra, N., Singh, A., Rana, N. P., Dora, M., \& Dwivedi, Y. (2018). Barriers to effective circular supply chain management in a developing country context. Production Planning and Control, 29(6), 551-569. https://doi.org/10.1080/ 09537287.2018.1449265

Mishra, D., Gunasekaran, A., Papadopoulos, T., \& Childe, S. J. (2018). Big Data and supply chain management: a review and bibliometric analysis. Annals of Operations Research, 270(1-2), 313-336. https://doi.org/10.1007/s10479-016-2236-y

Nyamu, K. (2012). Impact of Supply Chain Management Challenges on Humanitarian Organizations in Kenya. 53.

Paravisini, D., Rappoport, V., Schnabl, P., \& Wolfenzon, D. (2015). Dissecting the Effect of Credit Supply on Trade: Evidence from Matched Credit-Export Data. The Review of Economic Studies, 82(1), 333-359. https://doi.org/10.1093/restud/rdu028

Purnomo, E. P. (2012). The Stakeholders' Analysis and Development Indicator of Sustainability on the Community Project. SSRN Electronic Journal, (September 2011), 0-19. https:// doi.org/10.2139/ssrn.1818584

Schmidt, M. (2019). Sustainable Global Value Chains (Vol. 2). https://doi.org/10.1007/ 978-3-319-14877-9

SCI. (2020). Supply Chain Indonesia (SCI). Retrieved from https:// supplychainindonesia.com/

Sotiriadou, P., Brouwers, J., \& Le, T. A. (2014). Choosing a qualitative data analysis tool: A comparison of NVivo and Leximancer. Annals of Leisure Research, 17(2), 218-234. https:// doi.org/10.1080/11745398.2014.902292

Szerb, A. B., Horváth, T., Szerb, B., \& Csonka, A. (2020). Logistic Challenges in the Short Food Supply Chains. Regional and Business Studies, 10(2), 19-27. https://doi.org/ $10.33568 /$ rbs. 2378

Tseng, M. L., Islam, M. S., Karia, N., Fauzi, F. A., \& Afrin, S. (2019). A literature review on green supply chain management: Trends and future challenges. Resources, Conservation and Recycling, 141(June 2018), 145-162. https://doi.org/10.1016/ j.resconrec.2018.10.009

Urciuoli, L., \& Hintsa, J. (2017). Adapting supply chain management strategies to securityan analysis of existing gaps and recommendations for improvement. International Journal of Logistics Research and Applications, 20(3), 276-295. https://doi.org/10.1080/ 13675567.2016.1219703

Xu, X., \& Gursoy, D. (2015). A Conceptual Framework of Sustainable Hospitality Supply Chain Management. Journal of Hospitality Marketing and Management, 24(3), 229-259. https:// doi.org/10.1080/19368623.2014.909691 
Y.K Sharma. (2018). When challenges impede the process: for circular economy driven sustainability practices in food supply chain. (June).

Yalcin, H., Shi, W., \& Rahman, Z. (2020). A review and scientometric analysis of supply chain management (SCM). Operations and Supply Chain Management: An International Journal, 13(2), 123-133. https:// doi.org/10.31387/oscm0410257

Yazdani, M., Zarate, P., Coulibaly, A., \& Zavadskas, E. K. (2017). A group decision making support system in logistics and supply chain management. Expert Systems with Applications, 88, 376-392. https://doi.org/10.1016/j.eswa.2017.07.014

Zhao, R., Liu, Y., Zhang, N., \& Huang, T. (2017). An optimization model for green supply chain management by using a big data analytic approach. Journal of Cleaner Production, 142, 1085-1097. https://doi.org/10.1016/j.jclepro.2016.03.006 